\title{
PENERAPAN E-COMMERCE UNTUK MENGOPTIMALKAN PENJUALAN PADA TOKO GITA GIZA
}

\author{
Iqbal Rizqullah Arief ${ }^{1}$, Ita Novita ${ }^{2 *}$ \\ ${ }^{1}$ Fakultas Teknologi Informasi, Program Studi Sistem Informasi, Universitas Budi Luhur, Jakarta, Indonesia \\ Email: ${ }^{1}$ iqbal98arief@gmail.com, ${ }^{2 *}$ ita.novita@budiluhur.ac.id
}

\begin{abstract}
Abstrak-Dewasa ini perdagangan online atau e-commerce sangat diminati oleh masyarakat luas. Penjual dapat menjangkau target pasar yang lebih luas tanpa batasan wilayah dan memudahkan pembeli untuk mengakses menggunakan telepon genggam dan komputer dengan memanfaatkan jaringan internet tanpa harus datang secara fisik ke toko. Seperti halnya pada Toko Gita Giza yang merupakan usaha perorangan yang menjual berbagai model tas bermotif batik di daerah Tangerang Selatan. Saat ini Toko Gita Giza membuka toko offline dengan target masyarakat sekitar. Permasalahan yang terjadi saat ini adalah Toko Gita Giza masih kesulitan dalam mempromosikan produk-produk yang dijual dengan jangkauan pemasaran yang lebih luas dan kesulitan dalam memasarkan produk atau stok lama yang belum terjual. Dari pemasalahan tersebut penulis mengusulkan pembuatan e-commerce menggunakan Content Management System (CMS) yaitu wordpress dengan menggunakan metode Business Model Canvas (CMS) dan Search Engine Optimization (SEO). Hasil dari penelitian ini adalah berupa website e-commerce yang dapat membantu Toko Gita Giza untuk meningkatkan penjualan dengan memperluas target pasar ke seluruh pelosok indonesia maupun mancanegara.
\end{abstract}

Kata Kunci: E-commerce, CMS, BMC, Penjualan Tas, SEO

\begin{abstract}
Nowadays online commerce or e-commerce is in great demand by the wider community. Sellers can reach a wider target market without area restrictions and make it easier for buyers to access using cell phones and computers by utilizing the internet network without having to physically come to the store. Like the Gita Giza Shop, which is an individual business that sells various models of batik-patterned bags in the South Tangerang area. Currently, Toko Gita Giza is opening an offline shop targeting the local community. The current problem is that Gita Giza Stores are still having trouble promoting products that are sold with a wider marketing reach and difficulties in marketing products or old stocks that have not been sold. From these problems the authors propose making e-commerce using a Content Management System (CMS), namely wordpress using the Business Model Canvas $(C M S)$ and Search Engine Optimization (SEO) methods. The results of this study are in the form of an e-commerce website that can help Gita Giza Stores to increase sales by expanding the target market to all corners of Indonesia and abroad.
\end{abstract}

Keywords: E-commerce, CMS, BMC, Penjualan Tas, SEO

\section{PENDAHULUAN}

Dewasa ini konsep perdagangan online atau e-commerce makin berkembang dan banyak diminati oleh masyarakat luas. Konsep belanja yang lebih menguntungkan baik untuk pihak pelanggan maupun penjual dibandingkan konsep belanja model konvensional yang mengharuskan pelanggan datang langsung ke toko untuk berbelanja. E-commerce dapat menjangkau target pasar yang lebih luas tanpa batasan wilayah dan proses transaksi penjualan menjadi lebih mudah karena pelanggan dapat dengan cepat mengakses informasi secara detil mengenai produk yang ingin dibeli.

Pengertian e-commerce dalam [1] yaitu salah satu bentuk perdagangan elektronik digunakan untuk kegiatan transaksi penjual ke penjual ataupun penjual ke konsumen. Dengan sistem yang terintegrasi, pembuatan website ecommerce mampu menggabungkan seluruh komponen seperti pemesanan, pembayaran maupun pengiriman yang terdapat pada proses jual beli. Adapun beberapa komponen $e$-commerce dalam [2] yang dapat membentuk sebuah mekanisme pasar e-commerce yaitu konsumen, penjual, produk, front end, infrastruktur, back end dan partner bisnis.

Banyaknya model e-commerce yang tersedia saat ini juga dapat disesuaikan dengan kebutuhan unit usaha dalam mengelola penjualannya dengan tujuan untuk meningkatkan penjualan. Toko Gita Giza sebagai salah satu usaha perorangan yang berdiri sejak 17 Oktober 2017 bergerak dalam bidang penjualan tas bermotif batik di daerah Tangerang Selatan juga menginginkan hal yang sama. Yaitu dapat mengelola transaksi penjualan dengan baik sehingga bisa meningkatkan penjualan. Proses penjualan yang terjadi saat ini pada Toko Gita Giza adalah jika pelanggan berminat untuk membeli produk maka pelanggan harus datang langsung ke toko. Dimana target pasar Toko Gita Giza hanya masyarakat sekitar. Permasalahan yang terjadi pada Toko Gita Giza adalah masih kesulitan dalam mempromosikan produk-produk yang dijual dengan jangkauan pemasaran yang lebih luas, selain itu juga kesulitan dalam memasarkan produk atau stok lama yang belum laku terjual.

Berdasarkan permasalahan diatas, penulis mengusulkan pembuatan e-commerce pada Toko Gita Giza dengan tujuan untuk meningkatkan penjualan dengan memperluas target pasar ke seluruh pelosok indonesia maupun mancanegara. Adapun beberapa penelitian serupa yang telah dilakukan terkait pembuatan e-commerce yaitu seperti yang diterbitkan dalam [1] yang berjudul Perancangan Aplikasi Penjualan Tas dan Seminar Kir Berbasis E-commerce 
pada PT. RPM oleh Anas Buchari dan Yudi Santoso. Permasalahan yang terjadi di sana adalah adanya penumpukan barang di gudang serta kurangnya media pemasaran dan informasi. Untuk mengatasi hal tersebut maka dibutuhkan sistem informasi berbasis web yang mampu mengintegrasikan data perusahaan seperti produk, pelanggan dan mampu memasarkan produk tanpa batas dan waktu. Penelitian lain dalam [3] yang dilakukan oleh Handayani berjudul Perancangan Sistem Informasi Penjualan Tas Berbasis E-Commerce Studi Kasus Toko Kun Jakarta. Pernasalahan yang terjadi di sana adalah media promosi yang masih dilakukan dengan menggunakan spanduk. Penjualan yang dilakukan sebatas offline serta media penyimpanan berkas dan laporan masih dalam bentuk arsip. Untuk mengatasi hal tersebut, diusulkan sebuah website penjualan dalam bentuk e-commerce yang dijadikan sebagai media promosi, mempermudah dalam pengolahan data serta pembuatan laporan. Penelitian lainnya dalam [4] oleh Joko Setiawan berjudul Rancangan Sistem Informasi Penjualan Tas Berbasis Web Pada "Gikita" Online Shop. Kondisi saat ini, pemasaran produk Gikita Online Shop menggunakan media sosial seperti Facebook, Line, Messenger Blackberry, Whatsapp dan Instagram. Tujuan dari penelitian ini adalah untuk mendesain sebuah sistem informasi penjualan tas berbasis web untuk memudahkan pelanggan melakukan pembelian barang. CMS yang digunakan adalah Opencart. Hasil dari pembuatan website penjualan tas ini diharapkan dapat membantu memudahkan dalam pengelolaan barang dan dapat meminimalisir terjadinya kesalahan data.

\section{METODE PENELITIAN}

\subsection{Kerangka Pemikiran}

Kerangka pemikiran pada penelitian ini ditunjukkan pada Gambar 1.

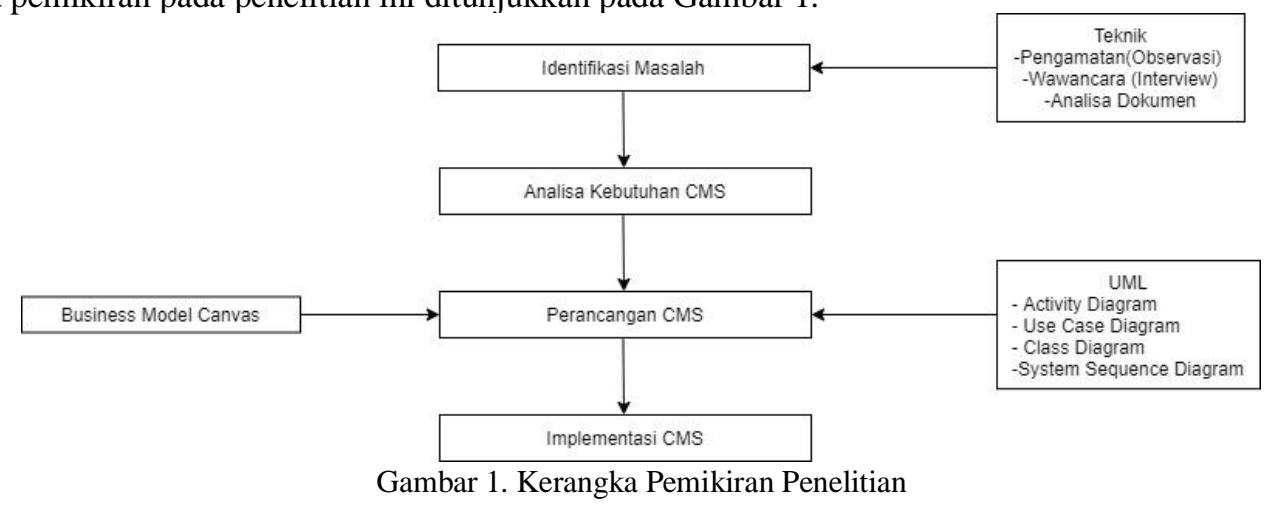

Berikut adalah penjelasan dari kerangka pemikiran Gambar 1:

a. Identifikasi Masalah

Pada tahap ini penulis melakukan identifikasi masalah dengan melakukan teknik wawancara, observasi dan analisa dokumen untuk mendapatkan informasi dan data yang sesuai dalam membantu merancang website $e$ commerce pada Toko Gita Giza.

b. Analisis Kebutuhan

Pada tahap ini penulis melakukan analisa kebutuhan sesuai dengan identifikasi masalah yang terurai di tahapan sebelumnya.

c. Perancangan

Pada tahap ini penulis melakukan perancangan dan desain sistem yang akan dibuat sesuai dengan kebutuhan ditahapan sebelumnya. Tools dan metode yang digunakan adalah UML dan BMC.

d. Implementasi

Pada tahap ini penulis melakukan implementasi sistem serta melakukan serangkaian pengujian untuk memastikan CMS berjalan dengan baik. Setelah itu menerapkan CMS yang sudah diuji kepada Toko Gita Giza.

\subsection{Metode Pengumpulan Data}

Berikut ini merupakan metode pengumpulan data yang digunakan oleh penulis untuk menyelesaikan penelitian yang dilakukan, antara lain :

a. Pengamatan (Observasi)

Penulis terlebih dahulu menentukan permasalahan secara garis benar, kemudian melakukan observasi ke Toko Gita Giza untuk melihat kondisi langsung di sana.

b. Wawancara (Interview)

Penulis melakukan wawancara dengan nara sumber pemilik Toko Gita Giza untuk mengetahui masalah secara jelas. 
c. Analisa Dokumen

Penulis melakukan analisa dokumen yang didapatkan di Toko Gita Giza untuk menentukan kebutuhan sistem.

\section{HASIL DAN PEMBAHASAN}

\subsection{Hasil Analisa Proses Bisnis Berjalan}

Tahapan awal untuk membantu Toko Gita Giza dalam menerapkan e-commerce adalah dengan melakukan penelusuran di setiap proses bisnis. Hal ini bertujuan untuk mendapatkan kebutuhan sistem dari setiap proses agar model aplikasi e-commerce pada Toko Gita Giza berjalan sesuai dengan proses bisnis berjalan. Untuk itu, langkah yang dilakukan penulis adalah membuat model bisnis. Sesuai referensi [5] model bisnis merupakan metode yang membantu perusahaan untuk bercerita mengenai kondisi internal perusahaan. Melalui Business Model Canvas (BMC) perusahaan dapat menampilkan secara sederhanan namun menyeluruh terhadap 9 komponen esensial dari bisnis. Adapun BMC pada Toko Gita Giza telihat pada Gambar 2.

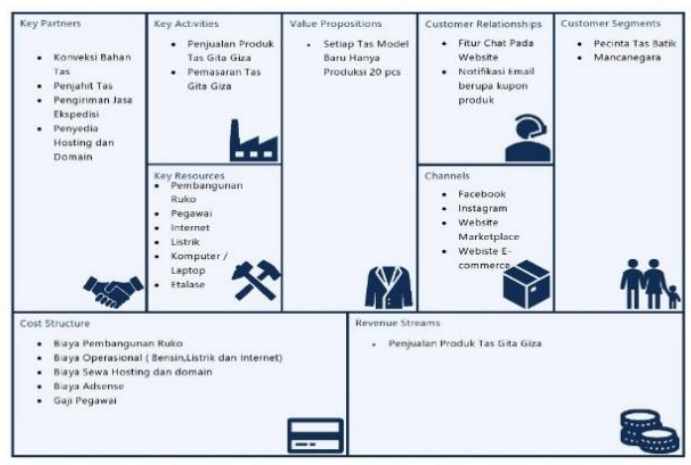

Gambar 2. Business Model Canvas PT. Gita Giza

Adapun penjelasan Business Model Canvas dari Gambar 2 adalah:

a. Customer Segments:Konsumen yang menjadi sasaran penjualan pada Toko Gita Giza adalah pecinta tas batik dan mancanegara.

b. Value Propositions: Memberikan produk terbatas kepada pelanggan, sehinnga setiap model baru produksi hanya 20 pcs.

c. Channels: Pemesanan dengan melalui website E-commerce Toko Gita Giza, sosial media dan website marketplace (Shopee, Tokopedia, Facebook dan Instagram).

d. Customer Relationships: Fitur chat pada website dan notifikasi email berupa kupon produk.

e. Revenue Streams: Keuntungan didapat dari hasil penjualan produk Tas Batik Gita Giza beberapa varian seperti Tas Jinjing, Ransel, Pouche dll.

f. Key Activities: Menjual produk Tas Gita Giza berbahan batik dan memasarkan produk tersebut.

g. Key Resources:Sumber daya yang penting bagi kelangsungan Toko Gita Giza adalah Bangunan Ruko, Bensin, Listrik, Internet, Adsense, Pegawai

h. Key Partnership : Konveksi pembuatan bahan tas, penjahit tas bahan batik, ekspedisi pengiriman barang, dan penyedia jasa layanan hosting dan domain.

i. Cost Structure: Biaya sewa ruko, gaji pegawai, biaya sewa hosting, biaya internet, dan biaya listrik.

\subsection{Hasil Perancangan Sistem}

Langkah selanjutnya yang dilakukan penulis adalah melakukan tahapan perancangan sistem dan perangkat lunak. Perancangan aplikasi e-commerce pada penelitian ini menggunakan CMS Wordpress. Dalam [6] wordpress adalah sebuah perangkat lunak yang bisa digunakan untuk membuat website, tidak hanya web pribadi dan situs berita, tetapi juga toko daring (online). Selain itu, wordpress memiliki beberapa keunggulan dalam [7] disebutkan diantaranya gratis, full control mulai dari security web maupun tampilan dan file editor semuanya ada dalam kontrol penuh, bebas mengupload dan menggunakan plugin gratis untuk menunjang performa web mengupload seperti SEO (Search Engine Optimizaton), dan lain-lain. Sedangkan untuk perancangan sistem, penulis menggunakan diagram UML seperti activity diagram, use case diagram dan class diagram.

a. Activity Diagram

Berdasarkan hasil wawancara dan analisis yang dibuat terdapat beberapa proses bisnis yang diusulan pada Toko Gita Giza. Proses bisnis tersebut terdiri dari proses pendaftaran, proses input produk, proses input kupon (pemasaran), 
proses penjualan, proses pembayaran, proses pengiriman dan proses laporan. Untuk contoh proses input kupon (pemasaran) dan penjualan ditunjukkan pada Gambar 3 dan Gambar 4.

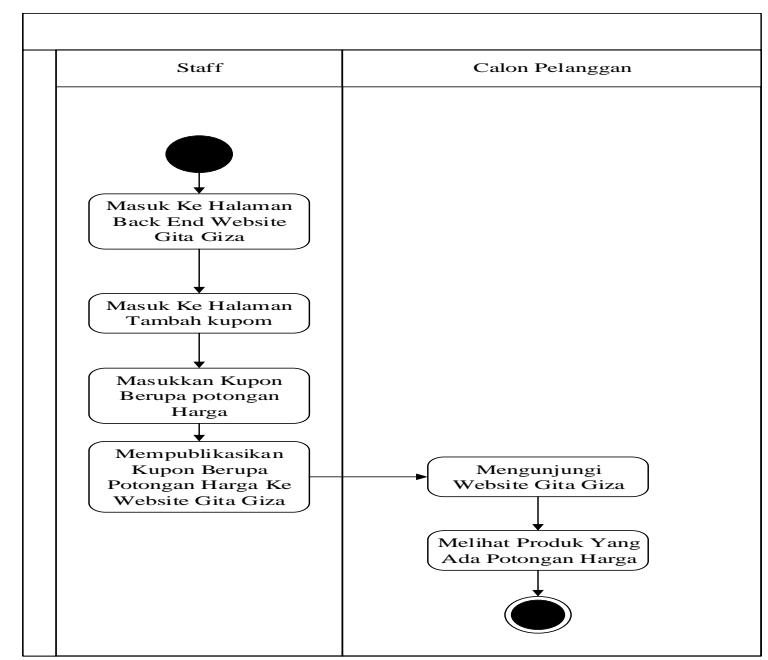

Gambar 3. Proses Bisnis Input Produk (Pemasaran)

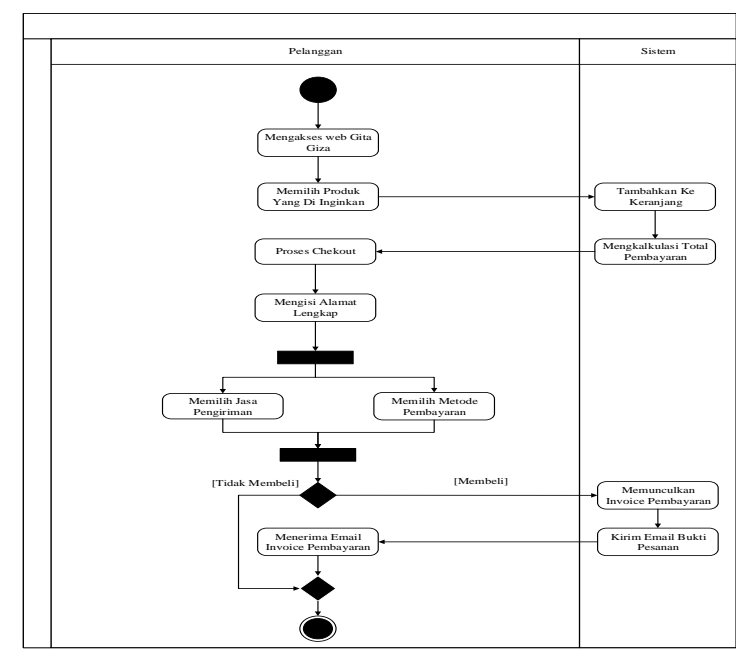

Gambar 4. Proses Bisnis Penjualan

Pada proses bisnis Gambar 3 dimulai dari staff masuk ke halaman back end website gita giza, staff masuk ke halaman tambah kupon, setelah itu staff masukkan kupon berupa potongan harga di produk, selanjutnya mempublikasikan kupon berupa potongan harga produk ke website gita giza. Saat calon pelanggan mengunjungi website gita giza, pelanggan dapat melihat produk yang ada potongan harga.

Pada proses bisnis Gambar 4 pelanggan dapat mengakses website gita giza, kemudian memilih produk yang diinginkan. Lalu pelanggan menambah produk ke keranjang, sistem mengkalkulasi total pembayaran, setelah itu pelanggan melakukan proses checkout, dan mengisi alamat lengkap, kemudian pelanggan memilih metode pembayaran dan jasa ekspedisi yang diinginkan, Jika pelanggan menjadi membeli maka sistem akan memunculkan invoice pembayaran, dan mengirim email invoive pembayaran ke pelanggan.

\section{b. Use Case Diagram}

Tahapan selanjutnya adalah mengindentifikasi kebutuhan sistem dengan menggunakan use case diagram yang dibuat dalam beberapa package yaitu use case diagram master, transaksi dan laporan. Untuk use case diagram master ditunjukan pada Gambar 5 yang menjelaskan tentang kebutuhan sistem untuk penginputan data master, dimana aktor yang terlibat adalah staf dan pelanggan.
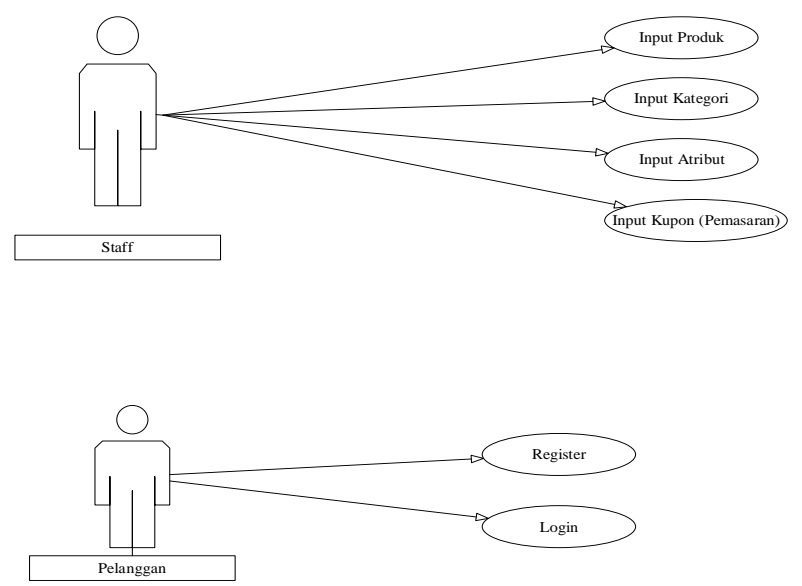

Gambar 5. Use Case Diagram Master

Pada use case diagram data transaksi terdiri dari use case diagram pilih pesanan, use case diagram pembayaran dan konfirmasi pembayaran serta use case diagram pengiriman yang ditujukan pada Gambar 6, 7 dan 8, dimana aktor yang terlibat adalah staf dan pelanggan. 

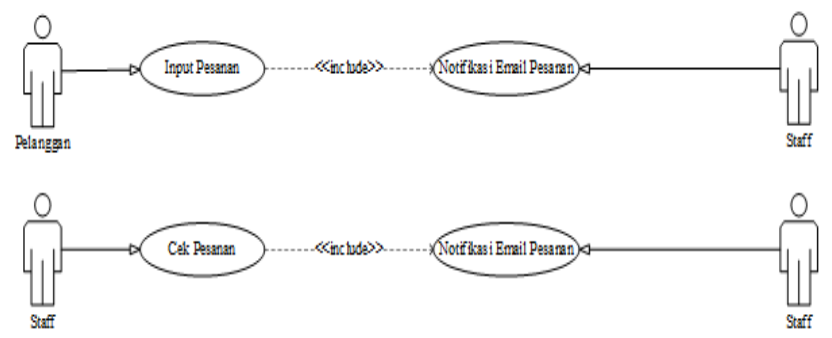

Gambar 6. Use Case Diagram Pilih Pesanan
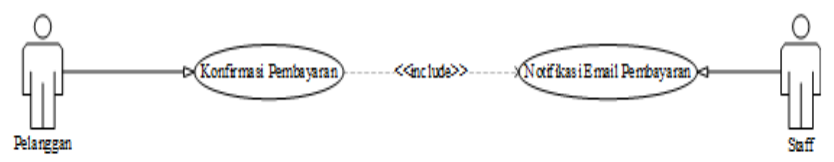

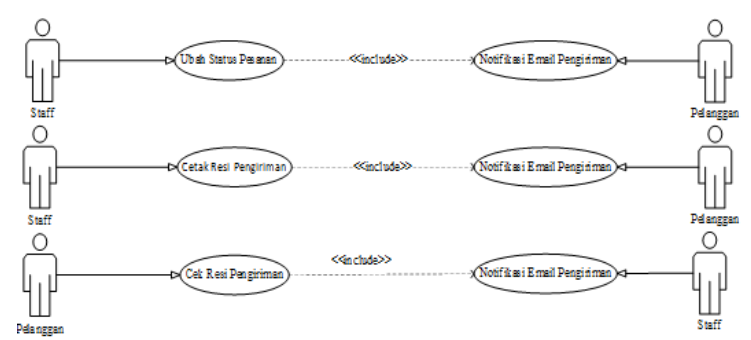

Gambar 8. Use Case Diagram Pengiriman

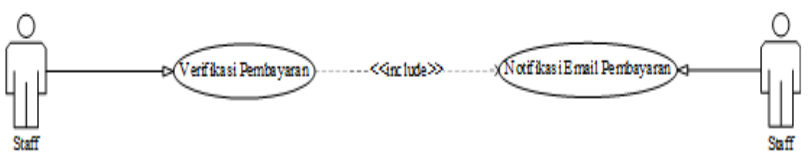

Gambar 7. Use Case Diagram Pembayaran dan Konfirmasi Pembayaran

Untuk use case diagram laporan terdiri dari use case diagram cetak laporan pemesanan, penjualan, pembayaran, pengiriman, produk terlaris, stok produk dan laporan kupon (pemasaran) yang ditujukan pada Gambar 9, dimana aktor yang terlibat adalah staf dan pemilik Toko.

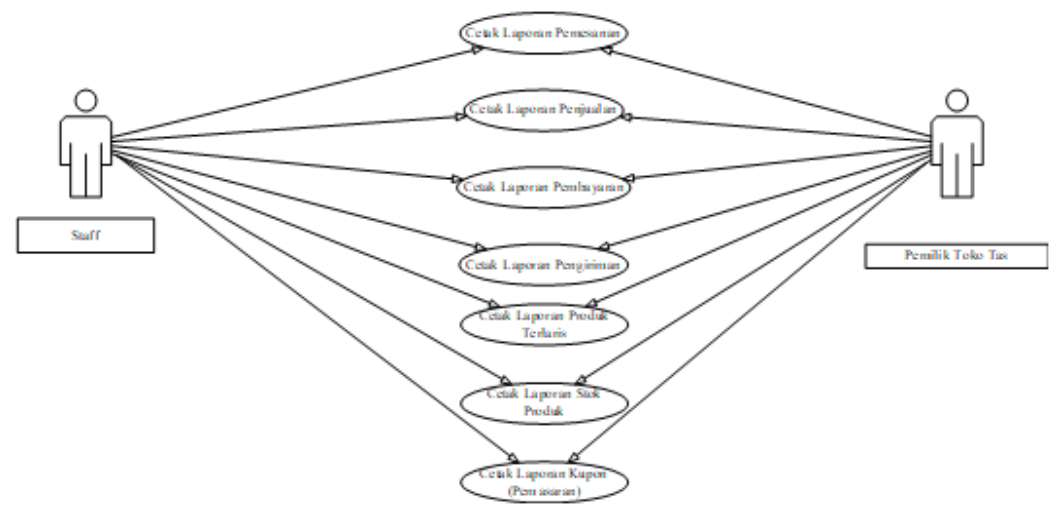

Gambar 9. Use Case Diagram Laporan

\section{c. Class Diagram}

Pada tahap selanjutnya penulis menjabarkan struktur sistem dari aplikasi e-commerce dengan menggunakan class diagram. Pada referensi [8] class diagram menjelaskan struktur dan kegiatan secara umum yang dilakukan oleh serangkaian objek. Objek terdiri dari kumpulkan class yang telah dibuat dan dimodifikasi selaam sistem diimplementasikan. Dalam aplikasi e-commerce memiliki sejumlah class yang dibentuk bertujuan untuk dapat memperlihatkan proses dari setiap class tersebut dalam menghasilkan sebuah informasi. Class diagram untuk aplikasi e-commerce pada Toko Gita Giza ditunjukkan pada Gambar 10. 


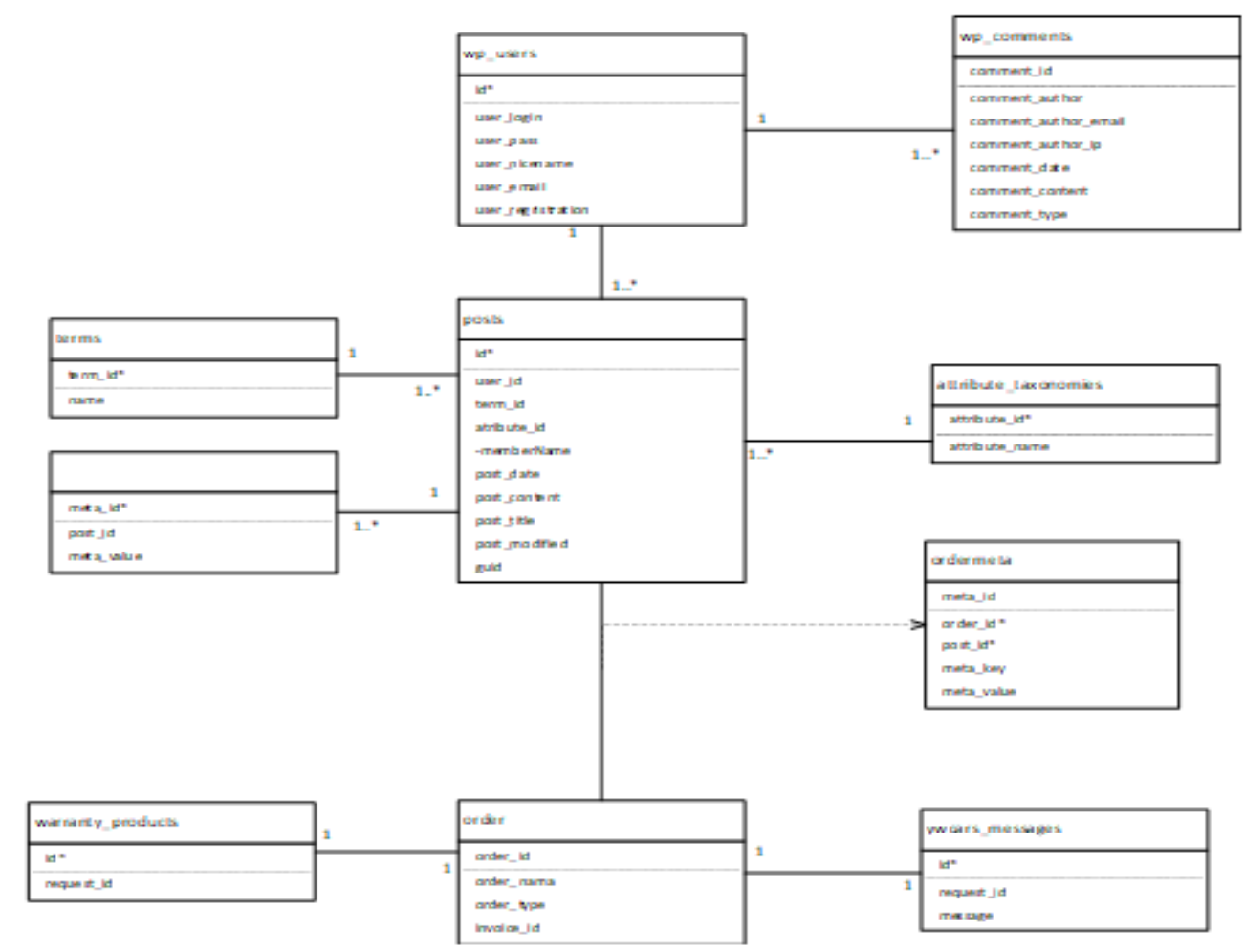

Gambar 10. Class Diagram Aplikasi E-commerce PT. Gita Giza

d. Struktur Tampilan, Rancangan Layar dan Output

1. Struktur Tampilan

Struktur tampilan aplikasi e-commerce pada Toko Gita Giza terdiri dari 2 sisi yaitu struktur tampilan Front End untuk publik dan Back End untuk admin. Untuk struktur tampilan pada sisi Front End menampilkan beberapa menu yang dapat membantu pelanggan dalam menemukan informasi seperti produk terbaru, melakukan pesanan, konfirmasi pembayaran, pengecekan resi, akun pelanggan, checkout pesanan serta pencarian produk tertentu yang ditujukan pada Gambar 11.

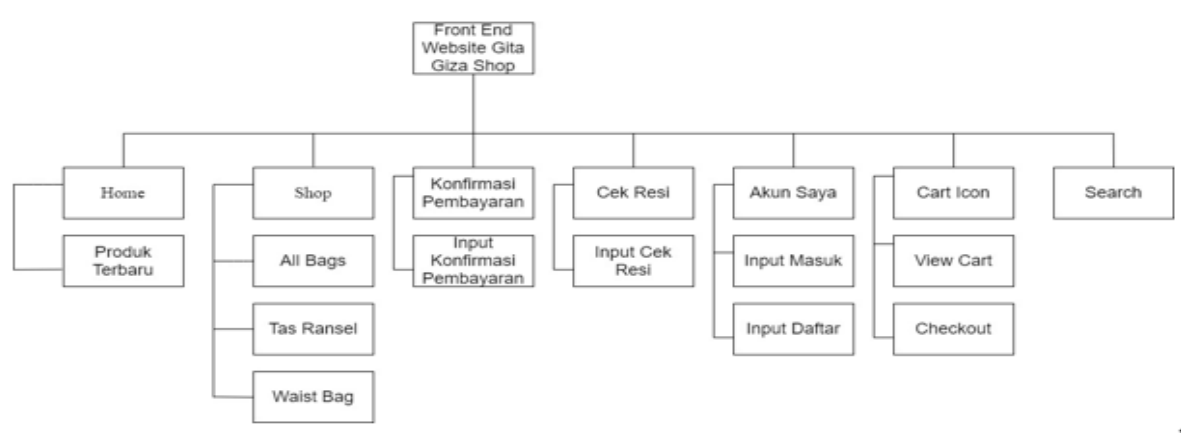

Gambar 11. Struktur Tampilan Front End

Untuk struktur tampilan dari sisi Back End pada Gambar 12 memperlihatkan beberapa menu untuk melakukan pengaturan aplikasi e-commerce seperti menu profil, dashboard, posting, media, page, comment, woocommerce, product, comfirm payment dan users. 


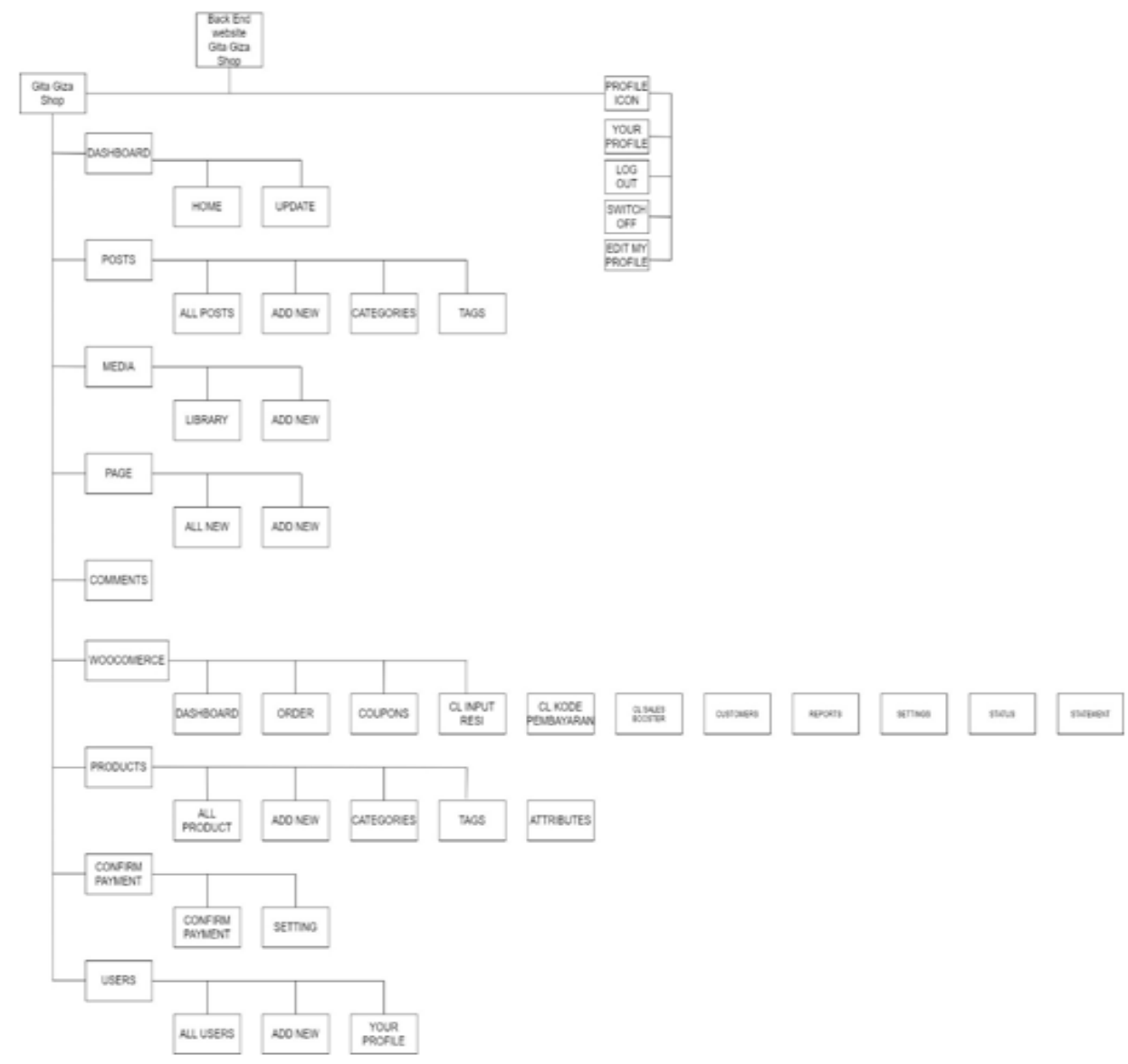

Gambar 12. Struktur Tampilan Back End

2. Rancangan Layar dan Output

Pada rancangan layar utama front end memperlihatkan rancangan layar home dari sisi pelanggn yang ditujukan pada Gambar 13. Pelanggan bisa melihat informasi produk dari Toko Gita Giza, layanan kurir serta informasi akun bank yang digunakan untuk transaksi pembayaran. Di layar home terdapat sub menu Shop, Kontak, Konfrimasi Pembayaran, Keranjang Belanja serta My Account.

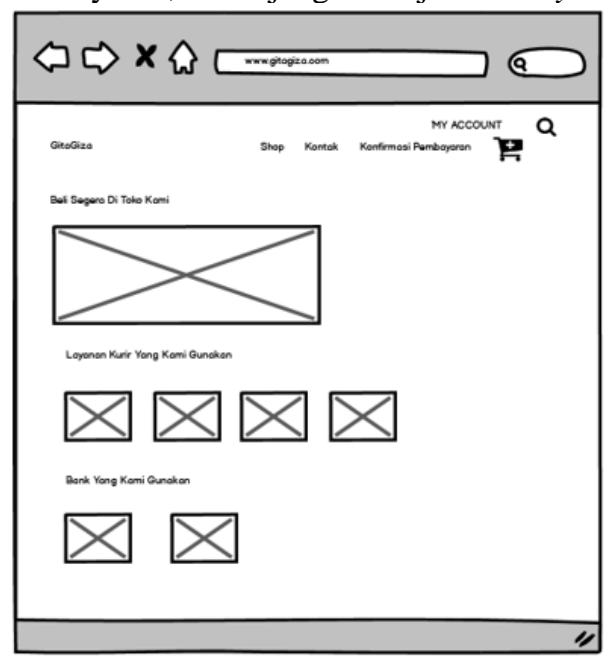

Gambar 13. Rancangan Layar Home

Rancangan layar untuk pelanggan yang ingin melakukan pemesanan produk terlihat pada Gambar 14. Pelanggan memasukkan jumlah produk yang ingin dipesan, kemudian memilih tombol tambah ke keranjang. Setelah pelanggan selesai melakukan pesanan, pelanggan mendapatkan konfirmasi pesanan dari Toko Gita Giza dalam bentuk email yang ditujukan pada Gambar 15. 


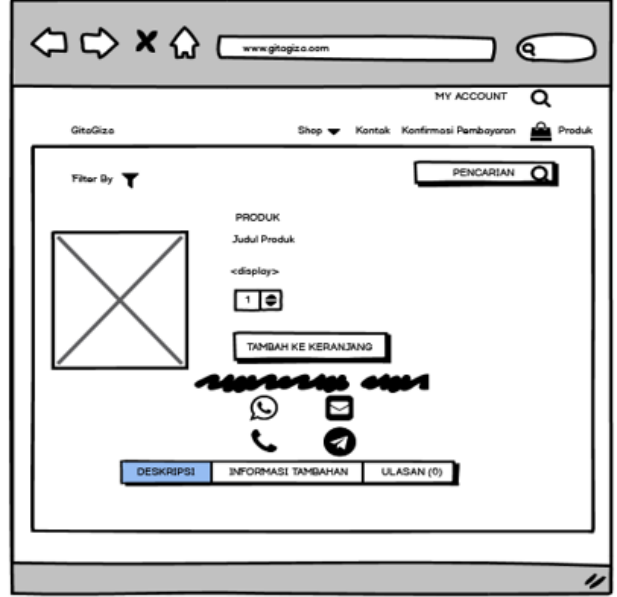

Gambar 14. Rancangan Layar Detil Produk Yang Dipesan

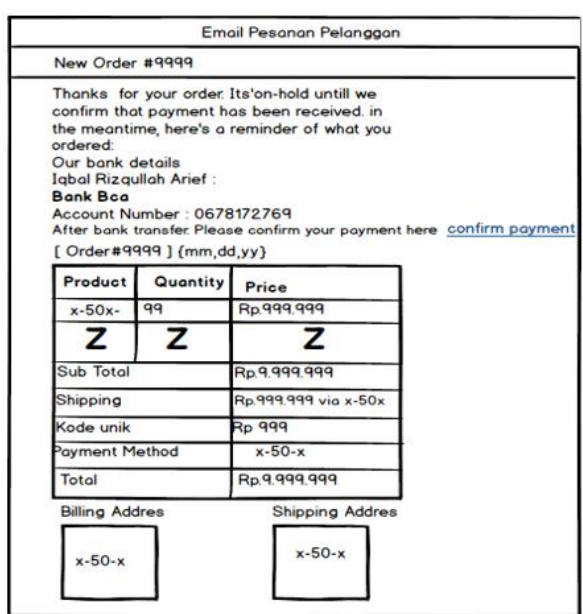

Gambar 15. Email Konfirmasi Pesanan

Untuk rancangan layar dari sisi Back End, staf dapat mengakses layar dashboard yang ditujukan pada Gambar 16. Pada tampilan utama dashboard terdapat informasi performance penjualan Toko Gita Giza yang terdiri dari informasi Total Penjualan, Penjualan Bersih, Pesanan, Nilai Pesanan Rata-Rata, Item Terjual, Pengembalian dan Penjualan Kotor. Sedangkan sebagai sarana pemasaran produk, staf bisa melakukan penginputan kupon yang terlihat pada Gambar 17. Staf bisa mengatur kupon apa saja yang bisa diset pada produk tertentu untuk periode tertentu kepada pelanggan.

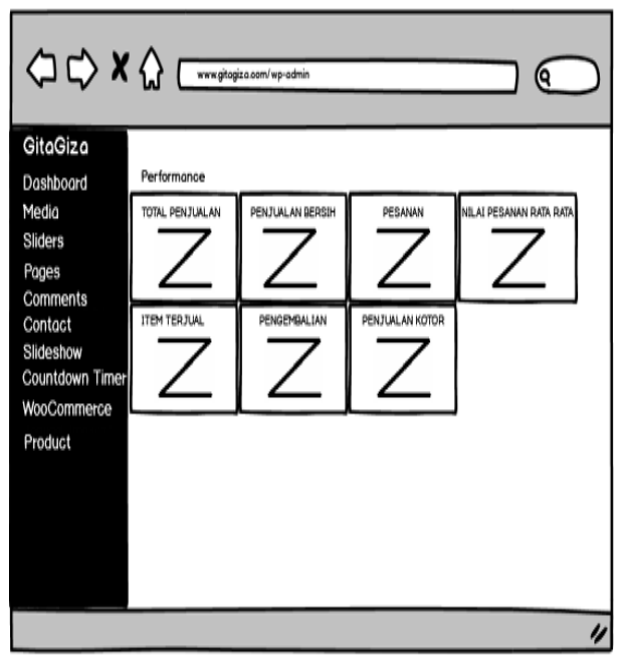

Gambar 16. Rancangan Layar Dashboard

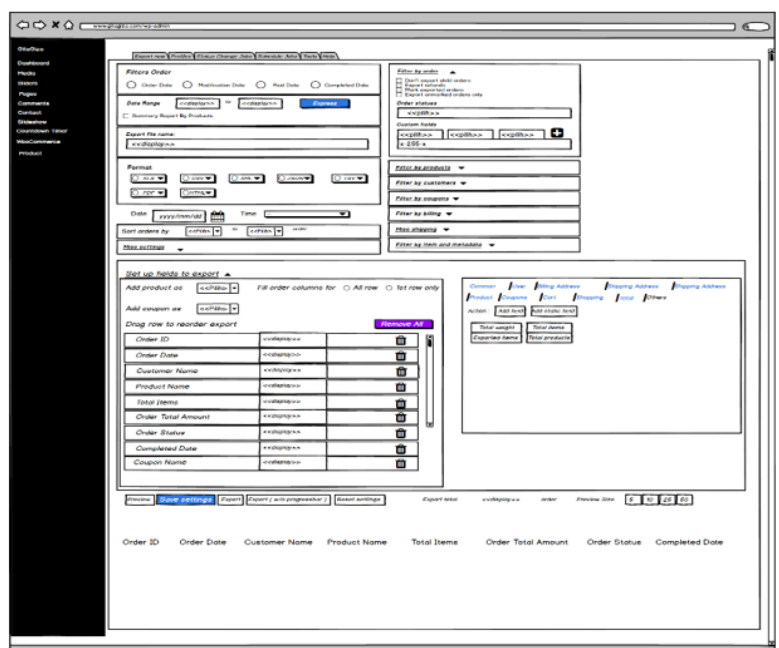

Gambar 17. Rancangan Layar Kupon (Pemasaran)

Untuk pelaporan tiap bulan yang ditujukan ke pemilik toko, penulis membuat beberapa rancangan layar laporan. Salah satu contoh rancangan layar yang dibuat adalah laporan penjualan. Laporan penjualan yang ditujukan pada Gambar 18 dibuat untuk mengetahui total penjualan produk tiap bulan dan rancangan outputnya terlihat pada Gambar 19. 


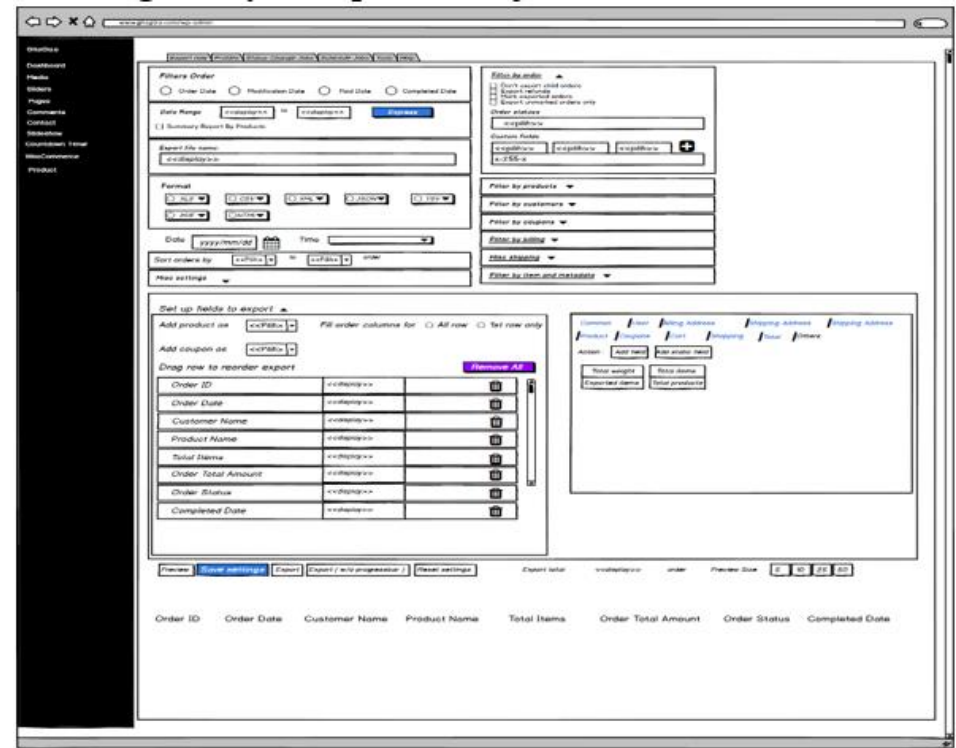

Gambar 18. Rancangan Layar Laporan Penjualan

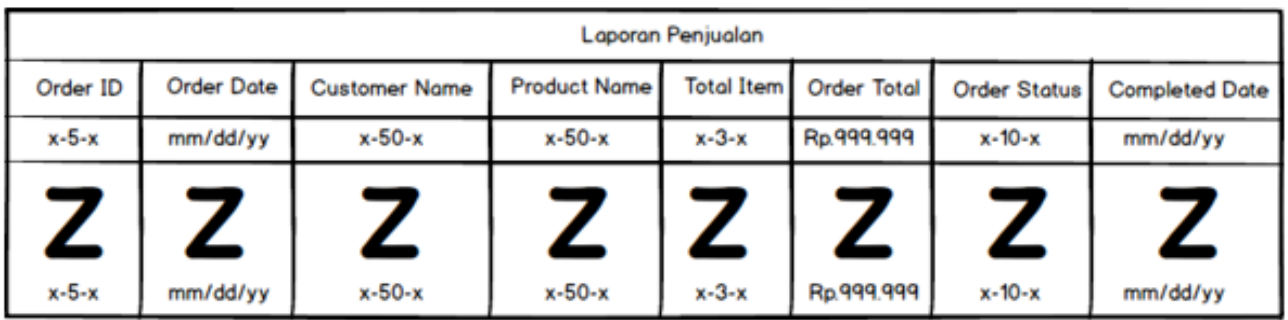

Gambar 19. Rancangan Output Laporan Penjualan

e. Strategi SEO dan Marketing

Sebagai tahapan akhir yang paling penting dalam menentukan keberhasilan penerapan website e-commerce pada Toko Gita Giza adalah strategi SEO (Search Engine Optimization) dan aktifitas marketing. Pada [9] strategi SEO merupakan serangkaian proses yang dilakukan secara sistematis bertujuan untuk meningkatkan volume dan kualitas trafik kunjungan melalui mesin pencari menuju situs web tertentu. Strategi SEO yang digunakan penulis pada penelitan ini adalah dengan strategi SEO On Page, menggunakan plugins Yoast SEO pada Nama Produk dan Kata Kunci, Deskripsi Produk, Gambar Produk, Meta Description, Focus Keyphrase dan Google Web Master Tool. Adapun hasil strategi SEO yang sudah dilakukan pada periode tertentu dimana website e-commerce Toko Gita Giza masuk kedalam halaman utama Google yang ditujukan pada Gambar 20.

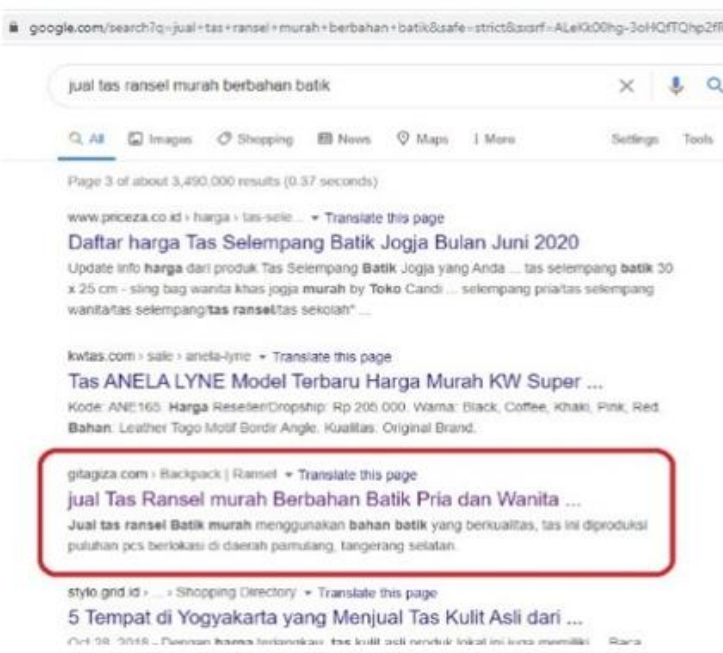

Gambar 20. Hasil Implementasi SEO 
Sedangkan untuk strategi marketing, pada [10] mempunyai peranan penting untuk mencapai keberhasilan usaha, dilakukan dengan menerapkan strategi yang akurat melalui pemanfaatan peluang dalam meningkatkan penjualan. Strategi marketing yang digunakan pada penelitian ini adalah strategi posting produk dan strategi kupon. Untuk strategi posting produk penulis menggunakan social media instragram yang terlihat pada Gambar 21 dan strategi kupon yang diberikan kepada pelanggan tertentu diberikan melalui website e-commerce Toko Gita Giza.

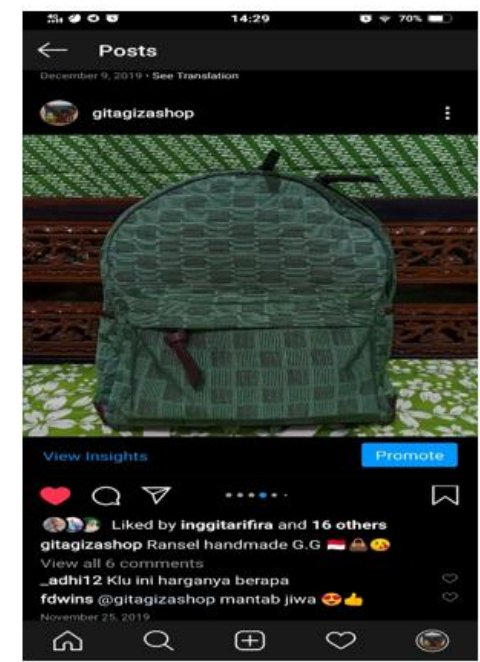

Gambar 21. Strategi Marketing via Instagram

\section{KESIMPULAN} yaitu:

Berdasarkan hasil pengamatan dan analisa yang dilakukan pada penelitian ini, maka didapatkan kesimpulan

a. Dengan adanya website e-commerce Toko Gita Giza akan sangat membantu pihak toko dalam membantu mempromosikan produk Toko Gita Giza sehingga dapat menjangkau area yang sangat luas, dan dapat menampilkan informasi produk yang lebih detail dan lengkap.

b. Dengan adanya website e-ccomerce pada Toko Gita Giza, memudahkan pihak toko dalam memberikan promo khusus berupa kupon produk potongan harga (sale), sehingga calon pelanggan akan tertarik mengunjungi website ini.

\section{DAFTAR PUSTAKA}

[1] A. Buchari and Y. Santoso, "Perancangan Aplikasi Penjualan Tas dan Seminar Kit," J. Idealis, vol. 2, no. 1, pp. 179-184, 2019.

[2] H. Himawan, A. Saefullah, and S. Santoso, “Analisa dan Perancangan Sistem Informasi Penjualan Online (E-Commerce) pada CV Selaras Batik Menggunakan Analisis Deskriptif,” Sci. J. Informatics, vol. 1, no. 1, pp. 53-63, 2015.

[3] S. Handayani, "Perancangan Sistem Informasi Penjualan Berbasis E-Commerce Studi Kasus Toko Kun Jakarta," Ilk. J. Ilm., vol. 10, no. 2.

[4] J. Setiawan, "RANCANGAN SISTEM INFORMASI PENJUALAN TAS BERBASIS WEB PADA 'GIKITA' ONLINE SHOP," Stat. F. Theor, vol. 53, no. 9, pp. 1689-1699, 2019.

[5] M. Rainaldo, B. M. Wibawa, and Y. Rahmawati, "Analisis Business Model Canvas Pada Operator Jasa Online RideSharing (Studi Kasus Uber di Indonesia),” J. Sains dan Seni ITS, vol. 6, no. 2, pp. 2-6, 2017.

[6] R. Rachmawati, "Teknik Dan Ideologi Penerjemahan Di Wordpress," Madah J. Bhs. dan Sastra, vol. 7, no. 2, p. 211, 2017, doi: 10.31503/madah.v7i2.430.

[7] A. Q. A. Dwi, "Pembuatan Website Menggunakan Cms Wordpress,” J. Apl. Bisnis, vol. 3, pp. 287-292, 2017.

[8] S. Kosasi, "Perancangan E-Commerce Accessories Handphone Berbasis Komponen," no. 372, 2014.

[9] R. Y. Endra and D. Prasetya, "Analisis Perbandingan Teknik SEO Antara Google Webmaster Dan Bing Master Menggunakan Gap Analisis,” Explor. J. Sist. Inf. dan Telemat., vol. 8, no. 1, 2017.

[10] F. Kereh, A. L. Tumbel, S. S. R. Loindong, J. Manajemen, U. Sam, and R. Manado, “Analisis Strategi Pemasaran Dalam Meningkatkan Penjualan Motor Yamaha Mio Pada Pt. Hasjrat Abadi Outlet Yamaha Sam Ratulangi,” J. EMBA J. Ris. Ekon. Manajemen, Bisnis dan Akunt., vol. 6, no. 2, pp. 968-977, 2018. 